\title{
Implementation of Oversight Policy, Apparatus Competence and Organizational Culture and its Effect on Performance of Field Supervision Basic Education
}

\author{
Muhamad Nur ${ }^{1}$, Khasan Effendy ${ }^{2}$, M. Aries Djaenuri ${ }^{3}$, Sampara Lukman ${ }^{4}$ \\ 1,2,3,4 Institut Pemerintahan Dalam Negeri (IPDN), Indonesia \\ Email: anuydy@gmail.com
}

\begin{abstract}
The administration of government requires a way of maximizing government management to achieve good governance to realize the welfare of the people and constitute demands of the constitution at the Preamble of the fourth Alenia 1945 Constitution. Article 31 of the 1945 Constitution states that Education is the right of every citizen, and the government and regional government guarantees the implementation of the national education system by Law Number 20 of 2003. This research aims to examine and analyze the effect of the implementation of supervisory policies, apparatus competencies, and culture organization of supervision performance in the field of primary education. The method used in this research is quantitative with open and closed questionnaires. The results of this study indicate that the causality relationship partially or simultaneously between the Implementation of Supervision Policy, Apparatus Competency, and Bureaucratic Culture to the Supervision Performance of the Basic Education Sector is entirely "positive and significant." Thus, the four hypotheses of this research are "accepted." Then, the results of the distribution of scores indicate that all dimensions of the variable values are higher than $90 \%$ and can be categorized as "Good." Based on the two analyzes, it can be stated that the Supervision Performance of the Basic Education Field held by the City of Depok, West Java Province is "Good." Conclusion This study shows that the Performance of Oversight in Basic Education goes well. This is evidenced by all four accepted hypotheses, and a positive and significant causality relationship. This was obtained by models and concepts in the field of education supervision. With the findings of the Actual Oversight Model, it is recommended for the government that this model can be used as input for the supervision policy formulation, Work Standards Criteria (KSK), and Education Supervision Performance Indicators (IKPP).
\end{abstract}

Keywords: Actual Oversight Model, Educational Oversight, Apparatus Competency, Organizational Culture, Oversight Performance.

\section{A. INTRODUCTION}

The existence of a state must have the purpose of being a state and nation, without exception the Unitary Republic of Indonesia (NKRI) also has the meaning as contained in the Preamble of the 1945 Constitution, the fourth paragraph, namely "Then, rather than that, to form an Indonesian government that protects all Indonesian 
people and all of Indonesia's blood and to promote public welfare, educate the life of the nation, and participate in carrying out world order based on independence, eternal peace, and social justice".

From a juridical perspective, the purpose of the Republic of Indonesia is contained in the 1945 Constitution article 1 paragraph (1), which reads, "The State of Indonesia is a unitary state in the form of a republic." As a republic, Indonesia has many obligations to its people, one of which is to educate the life of the nation and by Article 31 of the 1945 Constitution which reads, "(1) Every citizen has the right to education, (2) Every citizen must follow primary school and the government is obliged to finance it, (3) The government strives and organizes a national education system that enhances faith and devotion as well as noble character to educate the nation's life regulated by law, (4) The State prioritizes the education budget of at least $20 \%$ of the budget state revenue and expenditure as well as from the tax and budget regional spending to meet the needs of the implementation of national education, (5) the Government advances science and technology by upholding the values of religion and national unity for the advancement of civilization and the welfare of humanity". This can be concluded that the objectives of the Unitary Republic of Indonesia are the rights and obligations of the government and the people regarding education and culture.

These rights and obligations can be achieved, so that government management is needed is a process of carrying out "governance" or control of government by the authorities or administrators of the government to achieve predetermined goals, namely improving people's welfare (Supriyanto, 2009:24). The view of government management as "an activity or effort to achieve the goals of the state by using various sources controlled by the state. The core of government management lies in the process of mobilizing to achieve the goals of the state, which are closely related to education".

According to Sedarmayanti (2003:76), good governance is a form of development management, which is also called development administration. Thus he argues that the government is in a central position (agent of change) of a society in a developing nation. In good governance, not only government, but also citizens, the community in question is an organized society, such as NGOs, work associations, and even associations.

In line with this description, then to actualize the publication of Law Number 23 of 2014 concerning Regional Government, which has been amended several times. The purpose of this law is to realize the welfare of the regional community, which is done by improving the quality of services, community empowerment, and the construction of facilities and infrastructure in the regions worthy. Also, it is also to realize the effective management of natural resources and provide opportunities for local residents to participate in governance. With the implementation of the Act, it is hoped that the 
quality and competitiveness of autonomous regions will increase and can also have an impact on the progress and welfare of their communities.

In the implementation of the education system that takes place in various types and educational fields are an integral part of national development that aims to develop a Whole Indonesian Man and develop the entire Indonesian society. The implementation of the education system is a shared responsibility between the government, the community, the business world, industry, and families. Therefore, the implementation of the national education system needs to be optimized so that the goals of Whole Indonesian Human development and the development of the entire Indonesian Community through the application of various educational policies and activities can be maximally achieved. With the achievement of the goals of Whole Indonesian Human development and the development of the entire Indonesian Community, all aspects of family, community, nation, and country life will become more qualified, advanced, and prosperous. Also, through quality education, Indonesian people are also increasingly able to respond, overcome, and at the same time, be prepared to anticipate the dynamics of social change and the increasingly globalized development of society.

Indonesia's human development goals can be fully achieved if the function of education can be carried out effectively. Meanwhile, the development goals of all Indonesian people through the implementation of the education system can be achieved if the implementation of the education system can accomplish all educational targets throughout the country.

With the effectiveness of high management education, every individual indeed not only obtains the knowledge and technology needed to improve his competence, but also acquires an atmosphere of learning that strengthens achievement motivation. Therefore, the implementation of an adequate education management system functionally enhances the quality of student resources and is also useful for improving the quality of the educational environment. Thus, the implementation of an adequate education management system is an essential factor in the implementation of a national education system; and, at the same time, becomes an indicator of the ability of educational management in carrying out the education function.

To optimize the implementation of an education management system that further expands and deepens the mastery of science and technology and the formation of an increased quality mental attitude, the application of an education management system in various types and levels of education certainly not only requires the support of multiple resources, but also requires educational performance. Therefore, the organizers of the education management system, especially the management of primary 
education, are challenged to be able to improve professionalism in carrying out the functions of education management, so that the implementation of training is more effective.

The population of the City of Depok is based on 2016 population projections of $2,179,813$ people. The number consists of 1,098,473 inhabitants of the male population and 1,081,340 inhabitants of the female population. The sex ratio (male population versus female population) is 102, which means that in every 100 women, there are 102 men. Thus, showing the number of the male population and the name of the female population can be said to be balanced.

The total number of civil servants in Depok City is 7,146 people consisting of Group I as many as 50 people, Group II as many as 1,588 people, Group III as many as 3,220 people, and Group IV as many as 2,288 people (Source: City of Depok in Figures 2017). The number of civil servants involved in supervising primary education is 3,863 people. Thus the ratio of supervision of civil servants in the field of primary school compared to the total number of civil servants in Depok is 54.05\%. But when viewed from the ratio based on officials (echelon) supervision of primary education as many as 50 people with a rate of $6.37 \%$ of the total number of officials (echelon) in the City of Depok as much as 785 people. Based on the description, the supervision performance of the implementation of regional government affairs in the field of primary education can be said to be successful, but still leaves problems that can be said to be not optimal. This can be said to be complex and exciting to study.

\section{B. LITERATURE REVIEW}

\section{Government Science}

As a developing scientific discipline, Government Science has become very functional to criticize the implementation of government functions carried out by State government institutions. Furthermore, the dynamics of Government Science itself can be traced from the nature of Government Science, and the development of Government Science, including (1) The nature of government science revealed from the opinions of experts. As Van Poelje (1993: 1) argues: "De bestuurskel leert, hoe men de openbare diet het Beste inricht en leidt". The meaning is that the science of government teaches how public services are best arranged and led. (2) Development of Government Science. According to Ndraha (1997:9), in the first stage, the symptoms of governance are examined through the point of view and the way of seeking knowledge that existed at that time, so that the object becomes the scope and is studied as material or an integral part of other disciplines, such as Law, Political Science, Sociology, Economics, and Administrative Sciences. 


\section{Government Management}

Supervision is one of the functions of government management that takes place in the implementation of government functions. Government management is another designation of public administration. Talking about general management, means we are talking about control. Regarding management, Terry (1979: 3) said: Some argue that "Management is the act of thinking and achieving desired results through group efforts consisting of acts of utilizing human talents and resources." Other parties say that "Management is nothing but an effort to carry out certain things through humans." Briefly, people have stated management actions as actions to plan and implement it.

Thus management can be interpreted as a process of managing organizational resources and behavior to achieve specific goals or outcomes. The State Administration Institute (1978: 90) defines that Government Management is management that is applied in the environment of the state apparatus or government apparatus. Government apparatus or state apparatus is not only interpreted as the apparatus of the Executive body, but also the device of the Legislative and Judiciary bodies, both at the central and regional levels. With general principles of governance, management includes the division of labor, authority and responsibility, work mechanisms, rewards, work ethics, adjustments, struggle culture, and anticipation.

Government management is often also called public administration related to the implementation of government affairs. The development of this general management, then developed as the New Public Management (NPM). The concept of NPM is a new paradigm in public administration that is used to describe public sector reforms. The emergence of this concept is the existence of general dissatisfaction with government performance, which is considered inefficient and ineffective in managing resources. This dissatisfaction was triggered by the increasing state of government debt, high taxes, and declining economic growth.

\section{Public Policy Implementation Theory, Competency Theory, Organizational Culture Theory, Monitoring Performance Theory}

Applied Theory is a theory that is at the micro-level and is ready to be applied and conceptualized (Dougherty \& Pfaltzgraff 1990:10-11). The applied method is described to get a driven theory that can be used as a theoretical basis for the preparation of operational concepts for each research variable.

Referring to the issue of public policy implementation, Hill and Hupe (2002:7) said: Implementation is the carrying out of fundamental policy decisions, usually incorporated in a statute but which can also take the form of critical executive orders or 
court decisions. Ideally, that decision identifies the problem (s) to be addressed, stipulates the objective (s) to be pursued, and in a variety of ways, "structures" the implementation process. The process runs typically through several stages beginning with a passage of primary statutes, followed by the policy outputs (decisions) of the implementing agencies, the compliance of target groups with those decisions, the actual impact both intended and unintended of those outputs, the perceived effects of agency decisions, and finally, essential revisions (or attempted alterations) in the underlying statute.

Policy implementation, according to Hill and Hupe, is a decision that identifies problems and then looks for various ways of resolution by showing the structure of policy implementation that can be followed by policy implementers.

\section{Theory of Organizational Culture}

Organizational culture is the beliefs, norms, and work ethics and work behavior that takes place in every work unit of the government bureaucracy. Understanding of corporate culture covers the basic concepts of organizational culture. Culture is created so that people in social life cannot be separated from cultural ties. How the cultural ties are created by the community concerned, both in the family, organization, business, and nation. Thanks to culture can distinguish one group of people with another group. The difference can be seen from the way they interact and act in the completion of a job.

\section{Framework}

Performance of essential education supervision that is not optimal in overseeing the implementation of education management seems to be a phenomenon of the performance of the supervision bureaucracy that does not stand alone. That is, several variables correlate or affect the performance of the supervision. About this phenomenon, it is assumed that the Implementation of Basic Education Policy, Apparatus Competence that carries out the function of education supervision, and Organizational Culture that takes place in the administration of education are three variables that have a significant effect on the Performance of Supervision in Basic Education. This assumption is based on the following major premise:

1. First, Implementation of Supervision Policy, Competence of Apparatus and Organizational Culture influences Supervision Performance in Basic Education: Implementation of Supervision Policy, Competency of Apparatus and Organizational Culture is part of two conditions that affect organizational performance, namely: factors that directly touch (internal factors) and factors that are not directly in contact (external factors). Thus competence and motivation are 
internal factors that affect organizational performance, and are inherent in individual workers or personnel. While factors that indirectly come into contact with organizational performance in the form of regulations and corporate culture. Therefore, conditionally the Implementation of Supervision Policy, Apparatus Competency, and Organizational Culture influences the Supervision Performance of Basic Education. In this context, it is based on the view of Sluyter (1998: 14), which says that organizational performance has internal and external factors, namely: regulation, corporate culture, motivation, and competency. From this view, four study variables were obtained, namely: (1) organizational performance (effect variable); and (2) regulation, (3) corporate culture, and (4) competency (cause variable).

2. Second, the Implementation of Supervision Policy influences the Supervision Performance of Basic Education: Implementation of Policies that regulate the National Movement for the Acceleration of Completion of Nine-Year Compulsory Basic Education and Literacy Eradication is a regulation that is used as administrative and technical guidelines by school education management providers. Therefore, the functional implementation of the policy affects the performance of supervision in primary education, which is one of the functional components of education management.

3. Third, Apparatus Competence influences the Supervision Performance of Basic Education: Apparatus Competence that carries out the supervision function of education is the internal potential of the individual implementing the supervisory role. Therefore, the Apparatus Competency conditionally correlates or influences the Supervision Performance of Basic Education. In this context, Apparatus Competence is seen as the personality and ability of the apparatus of essential education supervision in carrying out the work revealed by Motives, Traits, Self-concepts, Knowledge, and Skills. This view is based on the opinions of Spencer and Spencer (1993: 9), which show five dimensions of competence, namely: Motives, Traits; Self-concept; Knowledge; and skills.

4. Fourth, Organizational Culture influences the Supervision Performance of Basic Education: Organizational culture that takes place in the implementation of primary education is beliefs, norms, and work ethics that correlate directly with the work activities of the organizers of education management. Therefore, conditionally Organizational Culture.

\section{Previous Research}

Minto Waluyo (2005) The Effect of Cigarette Prices, Organizational Culture, Market Orientation on Marketing Performance and Financial Analysis The Influence of 
Organizational Culture, Competence, and Organizational Commitment on Marketing Performance and Sustainable Competitive Advantage in Small Cigarette Companies Hand Clove Cigarettes in East Java, Postgraduate Programs Airlangga University, Surabaya, 2005. From the discussion of research results using a quantitative analysis approach based on the use of SEM Analysis,

the conclusion is that the price of cigarettes has a significant effect on marketing performance. Price has a big enough role on marketing performance, because price adjustment will improve marketing performance. Also, organizational culture has a significant effect on marketing performance. Corporate culture has a role to be used as a source of support for obtaining excellent marketing performance, and promotion has a significant impact on marketing performance. Advertising has a big enough role on marketing performance, because competition between small cigarette companies SKT is quite competitive. Promotion is used to move people to buy cigarettes.

Untung Subagyo, Miyasto, Idris, (2014), Analysis of the Effect of Organizational Culture, Competence, and Organizational Commitment on Employee Performance mediated by Work Motivation (Study on BPKP Representative in Central Java Province, Strategic Business Journal, Volume 23 No. 1 July 2014. From the discussion, the results of research using a quantitative analysis approach based on the use of SEM Analysis with AMOS 20.0 concluded that the influence of organizational culture on work motivation shows a standardized estimate of 0.231 and a CR value of 2.024 with a probability of 0.043 . Because the probability value $<0.05$ then indicates that organizational culture variables significantly influence motivation. Thus it can be concluded that organizational culture variables are proven to have a positive and significant effect on work motivation. The impact of competence on work motivation shows a standardized estimated value of 0.276 , and a CR value amounted to 2.131 with a probability of 0.033 . Therefore the probability value $<0.05$, it can be concluded that the competency variable is proven to have a positive and significant effect on work motivation.

\section{RESEARCH METHODS}

This research uses quantitative research. The quantitative analysis approach is carried out to determine the magnitude of the effect of the Implementation of Supervision Policy, Apparatus Competence, and Organizational Culture on Supervision Performance in Basic Education. The quantitative analysis was carried out using the SEM (Structural Equation Models Analysis) Analysis Method. Then, the SEM analysis results obtained by the Confirmatory Factor Analysis (CFA). CFA results are seen as 
research findings, and subsequently, based on CFA results, an analysis is carried out to obtain a new concept (Wijanto, 2008).

\section{RESULTS AND DISCUSSION}

SEM analysis results with a closed questionnaire can be divided into 3, namely the Recapitulation of Overall Model Fit Test Results (Overall Model Fit), Structural Model Fit Measurement Results, and Hypothesis Testing. Overall Model Match Test Results function to show the degree of compatibility between the data and the model. Structural Model Measurement Results and Hypothesis Testing that serves to show the significance and magnitude of the influence of exogenous latent variables on endogenous latent variables. The SEM analysis results are as follows:

\section{Recapitulation of Overall Model Match Test Results}

In this study, researchers used Structural Equation Modeling (SEM) with the LISREL program, where this method is used to test together models of independent variables and dependent variables. Independent variables include the Implementation of Supervision Policy, Apparatus Competency, Organizational Culture, and Variable Combinations. Combined variables are variables whose dimensions are obtained from the aspects of the Implementation of Supervision Policy, Apparatus Competency, and Organizational Culture. Dependent Variable is Supervision Performance in Basic Education. This has been tested for validity and reliability with the Confirmatory Factor Analysis (CFA) model. The next step is to analyze the results of the data compatibility test with the overall model using LISREL called the Degree of Match or Goodness of Fit (GOF).

The overall fit test results of the influence model of the Supervision Policy Implementation on the Supervision Performance of the Basic Education Sector can be concluded with a category that shows a good fit, because the estimation results for NFI, NNFI, CFI, IFI, and RFI are higher than the level of compatibility required as in table 4.8 (Hair et al. in Wijanto, 2008).

This compatibility means that the theory of public policy implementation according to Edward III (1980: 9-12) which is used as a theoretical basis for the preparation of operational concepts of variables and the preparation of research instruments can be declared suitable to uncover and discuss the effect of the Implementation of Supervision Policy on the Performance of Supervision of Basic Education held by the Depok City Inspectorate and the Depok City Education Office. Then the suitability is patterned based on the reference to the theory of public policy implementation according to Edward III (1980: 9-12) compiled in the form of conceptual 
definitions, dimensions of studies, and indicators on latent variables. Implementation of Supervision policies and developed according to the characteristics of the problem used as research objects, namely Performance Supervision of Basic Education organized by the Depok City Inspectorate and the Depok City Education Office.

While the results of the overall model fit to test the influence of Apparatus Competence on Supervision Performance in Basic Education can be concluded with a category that shows a good fit, because the estimation results for NFI, NNFI, CFI, IFI, and RFI are higher than the level of compatibility required. As in table 4.9 (Hair et al. in Wijanto, 2008). This compatibility means that the Competency theory according to Spencer and Sepencer (1993: 11) which is used as a theoretical basis for the preparation of operational concepts of variables and the preparation of research instruments can be declared suitable to uncover and discuss the effect of Apparatus Competence on the Performance of Supervision in Basic Education organized by the Depok City Inspectorate and Depok City Education Agency.

\section{Structural Model Testing Results and Hypothesis Testing}

Departing from the results of the measurement equation for exogenous latent variables Implementation of Supervision Policy, Apparatus Competency, and Organizational Culture and endogenous latent variables for Supervision Performance in Basic Education, then the structural equation measurement is performed which shows the influence of exogenous latent variables on endogenous latent variables. The results of the analysis of architectural models and testing hypotheses that refer to the 4 (four) conditional statements submitted in this study are as follows:

a. Based on the results of hypothesis testing, it is seen that the value is 14.96 (with a 95\% confidence level), and the required cut of profit is 1.96 ( $t$-value 1.96). It shows that the Implementation of Supervision Policy has a positive and significant to Supervision Performance in Basic Education. The magnitude of the effect is seen from the measurement of the path coefficient (path) of 0.94 . The size of the road indicates that the path coefficient can be said to be very strong (very significant) of the influence between the Implementation of the Supervision Policy and the Supervision Performance of the Basic Education Sector organized by the Depok City Inspectorate and the Depok City Education Office which established a meaningful causal relationship.

b. Based on the results of hypothesis testing, it can be seen from the presentation of the path diagram t-value of 14.14 (95\% confidence level) and the required cut of the value of 1.96 (t-value 1.96) indicating that Apparatus Competence has a positive effect and significant to the Supervision Performance in Basic Education. 
The magnitude of the impact of the measurement of the path coefficient, which shows 0.94 is greater than 0.50 , can be stated as a significant causal relationship. The influence shows that the Apparatus Competency with the Performance of Supervision of Basic Education organized by the Depok City Inspectorate and the Depok City Education Office is established a meaningful causal relationship.

c. Hypothesis testing results show that the $t$-value of 14.16 (95\% confidence level) and the required cut of the value of 1.96 ( $t$-value of 1.96), then indicate that the organizational culture has a positive and significant effect on Supervision Performance in Basic Education. The magnitude of this influence can also be seen from the results of the measurement of the path coefficient (path) of 0.94 higher than the required 0.50, and it can be stated that the relationship of influence is stable. The power shows that the Organizational Culture with the Performance of Supervision of Basic Education organized by the Depok City Inspectorate and the Depok City Education Office established a meaningful causal relationship.

d. The results of the measurement models in Table 4.17 show that the loading factor value each has a strong correlation to the construct of the exogenous late variable Organizational Culture. Referring to the overall examination of Innovation and Risk-Taking factor weights, Attention to Detail factors, Outcome Orientation factors, People Orientation factors, Team Orientation factors, Aggressiveness factors, and Stability factors revealed that all elements had given a significant loading factor to exogenous latent variables Organizational culture. This significance is known from the t-value higher than the Cut off Value (1.96), and the loading factor value is higher than the required amount of 0.50 . Thus the factors included in exogenous latent variables Organizational Culture has a statistically significant relationship to the construct, and manifest variables that make up the weight of each element can be declared valid.

Thus Attention to Detail as a factor in Organizational Culture in the implementation of Supervision Performance in the Basic Education Sector is essential, because Attention to Detail as a factor in Organizational Culture is one of the factors that determine the Performance of Supervision in Basic Education held by the Depok City Inspectorate and the Depok City Education Office. Attention to Detail Factors as Organizational Culture factors includes the following indicators: (1) Accuracy in supervision, (2) Accuracy in control, and (3) Prudential Supervision.

Based on the results of structural model measurements and hypothesis testing, as in Figure 4.5 shows that the seven dimensions of organizational culture studies include (1) Dimensions of Innovation and risk-taking, (2) Attention to detail dimensions, (3) Outcome orientation dimensions, (4) Dimensions People orientation, (5) Team 
orientation dimension, (6) Aggressiveness dimension, and (7) Stability dimension contribute to the process of establishing the magnitude of influence on the Performance of Supervision in Basic Education organized by the Depok City Inspectorate and the Depok City Education Office. The amount of contribution in the process of forming an influence on the Performance of Supervision of Basic Education is shown by the three dimensions of the variable Performance of Supervision of Basic Education, namely: (1) the aspects of determining the standard of performance of primary education supervision, (2) the dimensions of the actual performance evaluation of primary education supervision, and (3) the dimensions of feedback on the performance of primary education supervision.

\section{Quantitative analysis with Qualitative Data Analysis (QDA)}

The results of quantitative analysis using an extensive questionnaire using Qualitative Data Analysis Miner Lite 2.0.6 software. Great questionnaire data analysis techniques differ from quantitative data analysis with closed surveys. Application programs can assist in this quantitative analysis technique. Application is only a tool (tools), the success of quantitative analysis of open questionnaires (quantitative) still depends on the ability to think sharply and critical of the writer himself. The steps taken by the researcher in quantitative analysis with an open questionnaire first do the coding (coding), namely the process of combing transcripts written on public surveys, sketches, photos, or videos to search for topics, themes, ideas, concepts, categories, words keywords, or anything meaningful in them and then mark them. The coding framework (developing a coding scheme) is adjusted to the dimensions and indicators in the quantitative analysis of a closed questionnaire. However, if an open inquiry is used in the study, and transcripts from free surveys are found, sketches, photographs, or videos analyzed have no coding yet, a new coding is made.

Thus, it is necessary to revise the initial coding scheme (Revising the coding scheme). The analysis is needed sharpness of thinking as an instrument of research, so that revision in the implementation of research is a necessity. As New Coding is added, the coding framework becomes increasingly complex. Thus, it needs to be simplified (Simplifying the coding scheme), among others, by combining codes that have similarities into one new system that is more commonly called by adding new codes (Developing new laws).

\section{E. CONCLUSION}


Based on the results of the research and discussion, the end of the causal relationship between the independent variables and the dependent variable and the answers to the research hypotheses on the implementation of supervision performance in primary education in Depok City, are as follows:

1. There is a positive and significant effect between the Implementation of Supervision Policy and the Supervision Performance of the Depok City Basic Education Sector, amounting to 0.94. Thus the first hypothesis in this study was accepted. The influence shows that between the Implementation of the Supervision Policy and the Supervision Performance of the Basic Education Sector in the City of Depok, there is a meaningful causal relationship.

2. There is a positive and significant influence between Apparatus Competence and Supervision Performance in Basic Education in the City of Depok amounting to 0.94. Thus the Second Hypothesis in this study was accepted. The influence shows that the Apparatus Competency with the Performance of Supervision of Basic Education in the City of Depok established a meaningful causal relationship.

3. There is a positive and significant effect between Organizational Culture and Supervision Performance in Basic Education in the City of Depok, amounting to 0.95. Thus the Third Hypothesis in this study was accepted. The influence shows that between Organizational Culture and Performance of Supervision of Basic Education in Depok City, a significant causal relationship exists.

4. There is a positive and significant influence between the Combined Variables (Implementation of Supervision Policy, Apparatus Competency, and Organizational Culture) with Supervision Performance in the Basic Education Sector in Depok of 0.97 .

\section{REFERENCES}

1. Ainsworth, M, Smith, S., \& Millership, A. (2002). Managing Performance People. Jakarta: PT. Bhuana Ilmu Populer.

2. Apter, D. (1965). Comperative Politics. New York: The Free Press.

3. Basuki, J. (2007). Budaya Organisasi-Konsep dan Terapan. Jakarta: Yayasan Pembina Manajemen.

4. BPS. (2017). Kota Depok Dalam Angka Tahun 2017

5. LAN RI. (1997). Sistim Administrasi Negara Republik Indonesia. Jakarta: PT. Toko Gunung Agung.

6. Ndraha, T. (2011). Kybernology (Ilmu Pemerintahan Baru). Jakarta: Rineka Cipta. 
7. Ndraha, T. (1997). Budaya Pemerintahan dan Dampaknya Terhadap Pelayanan Masyarakat. Jurnal Ilmu Pemerintahan.

8. Sedarmayanti. (2003). Good Governance (Kepemerintahan Yang Baik) Dalam Rangka Otonomi Daerah. Bandung: Mandar Maju.

9. Spencer, L. M., \& Spencer, P. S. M. (1993). Competence at Work models for superior performance. John Wiley \& Sons.

10. Subagio, U., Miyasto, M., \& Idris, I. (2014). Analisis Pengaruh Budaya Organisasi, Kompetensi dan Komitmen Organisasi Terhadap Kerja Pegawai Yang Dimediasi Oleh Motivasi Kerja (Studi Perwakilan Bpkp Provinsi Jawa Tengah). Jurnal Bisnis Strategi, 23(1), 138-148.

11. Terry, G. R. (1979). Principles of Management. Bandung: Alumni.

12. Waluyo, M. (2005). Pengaruh Harga Rokok, Budaya Organisasi, Orientasi Pasar, Promosi Terhadap Kinerja Pemasaran dan Keunggulan Bersaing Berkelanjutan pada Perusahaan Rokok Kecil Jenis Sigaret Kretek Tangan di Jawa Timur (Doctoral dissertation, Universitas Airlangga). 